\title{
A novel promising Trichoderma harzianum strain for the production of a cellulolytic complex using sugarcane bagasse in natura
}

\author{
Bruno Benoliel ${ }^{1}$, Fernando Araripe Gonçalves Torres ${ }^{1}$ and Lidia Maria Pepe de Moraes ${ }^{1,2^{*}}$
}

\begin{abstract}
Brazil is a major producer of agro-industrial residues, such as sugarcane bagasse, which could be used as raw material for microbial production of cellulases as an important strategy for the development of sustainable processes of second generation ethanol production. For this purpose, this work aimed at screening for glycosyl hydrolase activities of fungal strains isolated from the Brazilian Cerrado. Among 13 isolates, a Trichoderma harzianum strain (L04) was identified as a promising candidate for cellulase production when cultured on in natura sugarcane bagasse. Strain L04 revealed a well-balanced cellulolytic complex, presenting fast kinetic production of endoglucanases, exoglucanases and $\beta$-glucosidases, achieving 4,022, U.L.-1 (72 h), 1,228 U.L.' (120 h) and 1,968 U...-1 (48 h) as the highest activities, respectively. About $60 \%$ glucose yields were obtained from sugarcane bagasse after 18 hours hydrolysis. This new strain represents a potential candidate for on-site enzyme production using sugarcane bagasse as carbon source.
\end{abstract}

Keywords: Sugarcane bagasse; Cellulases; Trichoderma harzianum; Brazilian Cerrado

\section{Introduction}

Lignocellulosic residues derived from different agroindustrial activities represent a massive source of raw material for the production of fuels, chemical feedstock, foods and livestock feeds (Kumar et al. 2008). Brazil is a major producer of renewable feedstock including sugarcane which is essentially used for sugar and fuel ethanol production. In 2010, sugarcane production reached $\sim 717.5$ million tons (FAOSTAT 2012). A significant fraction of this biomass goes to industries for steam and electricity generation. The remaining fraction represents the ideal feedstock for the generation of high-value commodities as second-generation ethanol (Canilha et al. 2012).

The use of lignocellulosic biomass for the production of second generation ethanol requires a pretreatment for the liberation of carbohydrate polymers. A number of different strategies have been envisioned to convert the polysaccharides into fermentable sugars. One of them is

\footnotetext{
* Correspondence: Imoraes@unb.br

${ }^{1}$ Centro de Biotecnologia Molecular, Departamento de Biologia Celular, Instituto de Ciências Biológicas, Universidade de Brasília, Brasília, DF, Brazil ²Laboratório de Biologia Molecular, Departamento de Biologia Celular, Universidade de Brasília, Brasília, DF 70910-900, Brazil
}

accomplished by weak acid (chloridric or sulfuric acid) treatment (Betancur and Pereira Jr. 2010) to hydrolyze the hemicellulose fraction. The resulting solid fraction is then depolymerized by a chemical or enzymatic treatment. The later involves the use of different classes of hydrolytic enzymes generally produced by filamentous fungi. The conversion of cellulose to glucose involves the concerted action of three classes of enzymes: endo$\beta$-1,4-glucanases (EC 3.2.1.4), exo-cellobiohydrolases (EC 3.2.1.91), and $\beta$-glucosidases ( $\beta$-D-glucosidic glucohydrolases, EC 3.2.1.21). Hydrolytic enzymes represent a considerable cost in industrial biofuel plants. On-site enzyme production has been proposed as a way of lightening this burden. A fraction of lignocellulosic material partially hydrolyzed is diverted from the process and used as a cheap carbon source for enzyme production. Consequent reductions in enzyme storage time and downstream processing can thus lower the overall costs (Himmel et al. 1999; Tolan 2002).

The capacity of a particular microorganism to grow in lignocellulosic substrates is directly related to the production of a broad spectrum of enzymes that act synergistically to deconstruct the plant cell wall by depolymerization of substrates of different complexities (Andreaus et al. 2008; 
Kumar et al. 2008; Siqueira et al. 2010; Moreira et al. 2012). An assorted library of cellulolytic microbes should facilitate the development of optimal enzyme cocktails specific for locally available lignocellulosic biomass, such as sugarcane bagasse.

The Cerrado is the main savanna-like region in the Americas covering about 2 million $\mathrm{km}^{2}$. Although considered an important biodiversity hotspot (Myers et al. 2000) its microbial diversity has not been thoroughly assessed for biotechnological purposes. Our group has previously isolated an xylanase producing yeast from de Brazilian Cerrado (Parachin et al. 2009). The objective of this work was to evaluate the production of cellulases by a set of filamentous fungi isolated from the Brazilian Cerrado aiming their use as a potential source for onsite enzyme production.

\section{Materials and methods}

Microorganisms and fungal isolation

Trichoderma reesei Rut-C30 (ATCC 56765) (Montenecout and Eveleigh 1977) was used as reference strain. Decaying leaf litter encountered in the Cerrado's soil from different areas around the city of Brasília was used as a source for fungal isolation. Collected samples were immersed in sterile distilled water and after vigorous agitation the suspension was subjected to serial dilutions and plated in a medium similar to the basic nutrient medium of Mandels and Weber (1969), with the exception that urea was omitted, a double amount of $\left(\mathrm{NH}_{4}\right)_{2} \mathrm{SO}_{4}$ was included, and the peptone content was elevated by $20 \%$ (Szijártó et al. 2004), supplied with $1 \%$ carboxymethyl cellulose. Plates with standard inoculum of $10^{3}$ spores were incubated for 5 days at $30^{\circ} \mathrm{C}$ following Congo red staining (Ruegger and Tauk-Tornisielo 2004). Positive cellulolytic colonies were picked up and subcultured on potato dextrose agar (PDA - $0.4 \%$ potato, $2 \%$ dextrose, $0.5 \%$ peptone, $2 \%$ agar) slants and grown at $30^{\circ} \mathrm{C}$ for 10 days.

Submerged fermentations were performed in $500 \mathrm{~mL}$ Erlenmeyer flasks. Total of $10^{6}$ spores were inoculated into $100 \mathrm{~mL}$ of modified basic nutrient Mandels and Weber medium (Szijártó et al. 2004) supplied with $10 \mathrm{~g}$. $\mathrm{L}^{-1}$ of different carbon sources. The cultures were incubated on a rotary shaker with an agitation rate of $200 \mathrm{rpm}$ at $30^{\circ} \mathrm{C}$ for up to 120 hours. Throughout the cultivation, aliquots were withdrawn, centrifuged at 20,000 $g$ for $5 \mathrm{~min}$ for cell and residual substrate analysis. Supernatants were stored at $-20^{\circ} \mathrm{C}$ until the enzyme assays were carried out. Three biological replicates were performed for each condition.

\section{Enzyme and protein assays}

Total cellulase, endoglucanase, and exoglucanase activities were determined using Whatman no. 1 filter paper (FPA), carboxymethyl cellulose (CMC, low viscosity), and microcrystalline cellulose (SIG) as substrates, respectively, according to standard conditions described by Ghose (1987). Reducing sugars, expressed as glucose liberated during reactions on FPA, CMC and SIG were quantified by the DNS method (Miller 1959). Endoxylanase activities were determined using xylan from oat spelts (XYL) as substrate according to Bailey et al. (1992). For all reactions one enzyme unit $(\mathrm{U})$ was defined as the amount of biocatalyst that releases $1 \mu \mathrm{mol}$ of the correspondent monosaccharide (xylose for xylanase and glucose for the other groups of enzymes) per minute under the assay conditions (30 min incubation at $50^{\circ} \mathrm{C}$ with $50 \mathrm{mM}$ acetate buffer $\mathrm{pH}$ 5.0). $\beta$-Glucosidase activity was assayed in a $100 \mu \mathrm{L}$ reaction mixture containing $3 \mathrm{mM} \rho$-nitophenyl- $\beta-D$ glucopyranoside (pNPG; Sigma, St. Louis, USA), $50 \mathrm{mM}$ acetate buffer ( $\mathrm{pH} 5.0$ ), and an appropriate dilution of enzyme preparation. After $10 \mathrm{~min}$ incubation at $50^{\circ} \mathrm{C}$, the reaction was stopped by adding $200 \mu \mathrm{L}$ of $1 \mathrm{M} \mathrm{Na}_{2} \mathrm{CO}_{3}$, and $\rho$-nitrophenol ( $\rho \mathrm{NP})$ release was monitored at $A_{405 \mathrm{~nm}}$. Enzyme unit was defined as the amount of biocatalyst that releases $1 \mu \mathrm{mol} \rho$-nitrophenol per minute under the assay conditions. Total extracellular protein content was measured using the Bio-Rad protein reagent according to the Bradford method (Bradford 1976) using bovine serum albumin (Sigma) as standard. All analyses were done in triplicate in a temperature-controlled incubator.

\section{Sugarcane bagasse hydrolysis}

In natura sugarcane bagasse (SCB), used as substrate in the hydrolysis assays, was provided by Costa Pinto Mill (Piracicaba, SP, Brazil). This biomass was also subjected to pretreatments to generate partially delignified cellulignin (PDC). Acid and alkali pretreatments were carried out to increase the cellulose content in the materials by removing the hemicellulose fraction and partially removing the lignin fraction, respectively. The acid pretreatment consisted of incubating the solid material with a $3 \%(\mathrm{v} / \mathrm{v})$ sulfuric acid solution (solid:liquid ratio of 1:4), while the alkali pretreatment was performed by incubating the material with a $\mathrm{NaOH} 4 \%(\mathrm{w} / \mathrm{v})$ solution (solid:liquid ratio of 1:20). Both pretreatments were carried out at $121^{\circ} \mathrm{C}$ (1 atm) for $20 \mathrm{~min}$.

Enzymatic hydrolysis was carried out using 1.0\% partially delignified cellulignin (PDC) or in natura sugarcane bagasse (SCB) using a SCB-induced (72 h) culture supernatant. Suspensions were incubated at $50^{\circ} \mathrm{C}$ in $50 \mathrm{mM}$ sodium citrate buffer ( $\mathrm{pH}$ 5.0) for $18 \mathrm{~h}$ with regular sampling. Glucose concentration was determined usinga kit based on the glucose oxidase assay $\left(\mathrm{Katal}^{\circ}\right)$ and total reducing sugar content was determined according to the method described by Miller (1959). The hydrolysis yield was determined using equation described by Maeda et al. (2011) from the carbohydrate contents of SCB and PDC previously determined by Castro et al. (2010a). 


\section{Gel electrophoresis and zymogram analysis}

SDS-PAGE analysis was performed to detect extracellular proteins. For visualization of carboxymethyl-cellulase and xylanase activities on gels a zymogram was performed according to Sun et al. (2008) with modifications. Briefly, proteins were separated on a 10\% SDS-PAGE gel with either $0.15 \%$ CMC (low viscosity sodium salt) or $0.15 \% \mathrm{XYL}$ (xylan from birch wood). The gel was washed twice in a solution of $0.5 \mathrm{M}$ sodium acetate and $25 \%$ isopropanol at room temperatureto remove SDS. Proteins were renatured in $50 \mathrm{mM}$ acetate buffer ( $\mathrm{pH} 5.0$ ) containing $5 \mathrm{mM} \beta$ mercaptoethanol by stirring the gel overnight at $4^{\circ} \mathrm{C}$. The gel was then incubated in $50 \mathrm{mM}$ acetate buffer (pH 5.0) at room temperature for $2 \mathrm{~h}$ followed by incubation at $50^{\circ}$ $\mathrm{C}$ for another $2 \mathrm{~h}$. The gel was stained in $0.2 \%$ Congo red for $1 \mathrm{~h}$ and distained with $1 \mathrm{M} \mathrm{NaCl}$.

\section{Molecular identification}

Standard protocols were followed for DNA manipulations (Sambrook and Russel 2001). Total fungal DNA was obtained from a mycelium grown on PDA as described by Roeder and Broda (1987). Ribosomal internal transcribed spacer (ITS) region was amplified from genomic DNA by PCR using primers ITS1 (5'-GCGGAT CCGTAGGTGAACCTGCGG) and ITS4 (5'-GCGGA TCCTCCGCTTATTGATATGC) (White et al. 1990). Double-stranded DNA sequencing was performed with the MegaBACE ${ }^{\bullet}$ Dye Terminator kit (GE Healthcare). Computer sequence analysis was carried out using the Phrap and Phred programs (Ewing et al. 1998).

Fungal isolates were identified via ITS sequence analysis using BLASTn search tools (www.ncbi.nlm.nih.gov). For taxonomic considerations, the obtained sequences were also used to include related species into phylogenetic trees. Sequence alignment was carried out using CLUSTALW (http://www.ebi.ac.uk/Tools/msa/clustalo/). Phylogenetic analysis was performed using MEGA v 4.0 software (Tamura et al. 2007). Bootstrap resampling analysis for 1000 replicates was performed to estimate the confidence of results. The DNA BarCode method for Trichoderma identification was carried out using the TrichOKEY v. 2 program (Druzhinina et al. 2005).

\section{Results}

In a screening for cellulolytic activity a total of 13 isolates (L01-L13) from decaying leaf litter were selected after growth on cellulose as sole carbon source. Sequence analysis of PCR-amplified fungal ITS revealed a wide diversity of fungal taxa representing five genera: Trichoderma (5), Penicillium (4), Aspergillus (2), Pestalotiopsis (1) and Curvularia (1). All thirteen isolates demonstrated the ability to growth on cellulose as sole carbon source, but only four (L04, L08, L10, L11) showed a significant CMC hydrolysis halo when submitted to a rapid screening for cellulolytic activity on Congo red plate assay. The L04 isolate presented the fastest growth occupying all $9 \mathrm{~cm}$ diameter plate area in about 3 days while L10 took 4 days. Isolates L08 and L11 presented slower growth on CMC medium although the best colony/halo ratios, 0.72 and 0.63 , respectively. No significant growth and/or activity hydrolysis halo on cellulosic substrate were observed in the other strain plates, therefore L04, L08, L10 and L11 isolates were selected for further studies.

To evaluate the cellulolytic productivity of the four selected isolates, submerged fermentation using $\mathrm{CMC}$ as sole carbon source was carried out for up to 120 hours. Every 24 hours, samples were withdrawn and assayed for cellulase activity. All analyzed isolates showed similar exoglucanase productivity when CMC was used as carbon source; the highest values observed were all around 1,200 U.L. $L^{-1}$ in a culture time of 72 hours. L04 excelled at the endoglucanase productivity when compared to the others analyzed fungi, reaching the value of 2,206 U.L $L^{-1}(72$ h). It represents about 6 times the production of L08, L10 and L11 at the same point of the growth curve. The production of $\beta$-glucosidase was also analyzed. The maximum activity detected for L04 was 2,938 U.L $\mathrm{L}^{-1}(120 \mathrm{~h})$, although at 96 hours of culture 2,350 U.L ${ }^{-1}$ has been achieved.

To evaluate the cellulolytic production ability of the selected strain in a complex substrate, SCB was used as carbon source in a submerged fermentation. Strain L04 demonstrated to be more efficient than the others analyzed strains when grown on SCB. The L04 maximum activities for endoglucanase, exoglucanase and $\beta$-glucosidase when grown on this substrate were 4,022 U.L ${ }^{-1}(72 \mathrm{~h}), 1,228$ U.L. $\mathrm{L}^{-1}(120 \mathrm{~h})$ and $1,968 \mathrm{U} . \mathrm{L}^{-1}(48 \mathrm{~h})$, respectively. SCB seemed as a poor cellulase inductor for the other analyzed strains. No activities or very low endoglucanase and $\beta$-glucosidase activities were detected in the supernatant from L08, L10 and L11, and the maximum exoglucanase activity detected reached half of the values obtained by L04 on this substrate.

In terms of volumetric productivity, strain L04 reached the maximum values as early as 24 hours for $\beta$-glucosidase (52.0 U. $\left.\mathrm{L}^{-1} \cdot \mathrm{h}^{-1}\right)$ and 48 hours for endoglucanase $(64.2$ $\mathrm{U} \cdot \mathrm{L}^{-1} \cdot \mathrm{h}^{-1}$ ) when SCB was used as inducer (Table 1 ). When T. reesei Rut C30 was grown on SCB as carbon source, it presented maximum volumetric productivity values for endoglucanase, exoglucanase and $\beta$-glucosidase of 38.6 U.L $L^{-1} \cdot h^{-1}(72 h), 14.2 ~ U . L^{-1} \cdot h^{-1}(24 h)$ and $29.3 \mathrm{U} \cdot L^{-1} \cdot h^{-1}$ (48 h), respectively. The $T$. reesei Rut C30 maximum detected activities for endoglucanase, exoglucanase and $\beta$ glucosidase when grown on this substrate were 3,795 U.L ${ }^{-1}$ (192 h), 567 U.L ${ }^{-1}$ (120 h) and 1,979 U.L ${ }^{-1}$ (192 h), respectively. Strain L04 was identified as Trichoderma harzianum (Hypocrea lixii) by phylogenetic analysis of its ITS1/2 regions and was selected for further analysis. 
Table 1 Maximum values of volumetric productivity observed for cellulases production by Cerrado isolates

\begin{tabular}{lcccc}
\hline Strain & Substrate & Endoglucanase & Exoglucanase & $\beta$-glucosidase \\
\hline L04 & CMC & $30.6 \pm 1.2(72)$ & $25.9 \pm 2.0(24)$ & $24.5 \pm 1.0(96)$ \\
& SCB & $64.2 \pm 6.4(48)$ & $10.2 \pm 1.2(120)$ & $52.0 \pm 0.4(24)$ \\
L08 & CMC & $20.2 \pm 1.2(24)$ & $24.9 \pm 1.5(48)$ & ND \\
& SCB & ND & $6.3 \pm 0.3(96)$ & ND \\
L10 & CMC & $8.8 \pm 0.3(24)$ & $30.9 \pm 1.2(24)$ & ND \\
& SCB & $2.9 \pm 0.1(48)$ & $36.8 \pm 1.4(24)$ & ND \\
L11 & CMC & $10.6 \pm 0.7(24)$ & $25.2 \pm 1.7(48)$ & $4.5 \pm 0.2(48)$ \\
& SCB & ND & $12.2 \pm 0.5(24)$ & ND \\
\hline
\end{tabular}

Volumetric productivity $\left(\mathrm{U} \cdot \mathrm{L}^{-1} \cdot \mathrm{h}^{-1}\right)$. Values in parentheses correspond to time of fermentation (h) when maximum results were observed. Not detected activity (ND).

The L04 enzymatic profile produced on SCB presented more xylanase, endoglucanase and $\beta$-glucosidase activities, even when grown on specific substrates (Table 2). However, partially delignified cellulignin (PDC) showed to be a poor inducer of L04 cellulolytic system (data not shown).

PDC and SCBwere subjected to enzymatic saccharification using the enzymatic cocktail produced by L04 grown on SCB. The enzyme/biomass loading ratio at this assay was equivalent to $5.0 \mathrm{FPU} / \mathrm{g}$ substrate. Figure 1 presents the temporal profile of the concentration of reducing sugars and glucose released by enzyme extract. After $18 \mathrm{~h}$ of saccharification, the L04 extract was able to release 4.32 g. $\mathrm{L}^{-1}$ of total reducing sugars from $\mathrm{SCB}$ and 8.16 g. $\mathrm{L}^{-1}$ from PDC. Glucose contents were also measured presenting values of 2.28 g.L $\mathrm{L}^{-1}$ from SCB and 4.48 g.L $\mathrm{L}^{-1}$ from PDC after $18 \mathrm{~h}$ of substrate hydrolysis. The released glucose concentrations were higher for PDC than SCB, however, in terms of glucose yield after $18 \mathrm{~h}$ of hydrolysis, calculated from the cellulose contents of SCB and PDC, the values were not different. The hydrolysis yield determined using $\mathrm{SCB}$ and $\mathrm{PDC}$ were $60.32 \%$ and $59.35 \%$, respectively.

To detect cellulolytic and xylanolytic activities in L04 enzymatic cocktail used in the saccharification assay, electrophoretic analysis on SDS-PAGE and zymographic assays was also performed. The L04 protein profile presented two distinct molecular mass cellulolytic activities, $\sim 50 \mathrm{kDa}$ and $20 \mathrm{kDa}$ (Figure 2, lane 3). Xylanolytic activities were also detected as a defined $20 \mathrm{kDa}$ band and multiple activities over $75 \mathrm{kDa}$ (Figure 2, lane 5).

\section{Discussion}

In nature, the breakdown of plant materials is done primarily by fungi. In its natural environment saprophytic fungi can colonize the leaf litter and woody debris in humus or associated with plant matter in the soil. In order to grow on theses complexes substrates the ability to produce a broad spectrum of protein and polysaccharide hydrolyzing enzymes is required. For this reason, samples were collected from the Brazilian Cerrado environment and the fungi biodiversity analysed .

The wide diversity of fungal taxa found on Cerrado samples and the predominance of Trichoderma and Penicillium genera were expected, since the technique employed favors the isolation of the most common and abundant fungi (often referred as "generalists") (Jeewon and Hyde 2007). The saprophytic condition of the Cerrado's isolates reinforces their ability to use lignocellulose as carbon source, however not all of the isolated fungi were able to secrete significant amounts of cellulase activities for biotechnological use.

The strain L04 identified as Trichoderma harzianum, when grown on SCB presented the best ratios of cellulase production among all analyzed strains including T. reesei Rut C30. T. harzianum are frequently reported as control agent against fungal pathogens (Arantes and Saddler 2010; Banerjee et al. 2010). However, recent studies have also revealed the potential of this fungus for cellulase production and industrial applications (Ahmed et al. 2009; Castro et al. 2010a, 2010b). Likewise, T. harzianum has also become a promising system for xylanase production under appropriate conditions (Franco et al. 2004).

Castro et al. (2010b) had previously shown that T. harzianum IOC3844 exhibited an expressive production of endoglucanase activity with a fast kinetics with the exponential production phase detected between 31 and 72 hours of fermentation after a short lag phase. In this work, under the same assay conditions, strain L04 showed a shorter lag phase with an earlier exponential production phase starting before 24 hours when grown on $\mathrm{SCB}$. Our results have shown that, unlike the other fungi

Table 2 Maximum values of volumetric productivity observed for production of cellulases by T. harzianum L04 strain grown on different carbon sources

\begin{tabular}{lccccc}
\hline Subtrate & Endoglucanase & Exoglucanase & Total cellulase & B-glucosidase & Xylanase \\
\hline SCB & $64.2 \pm 6.4(48)$ & $10.2 \pm 1.2(120)$ & $15.4 \pm 0.2(48)$ & $52.0 \pm 0.4(24)$ & $135.7 \pm 1.7(48)$ \\
CMC & $30.6 \pm 1.2(72)$ & $25.9 \pm 2.0(24)$ & $3.8 \pm 0.3(24)$ & $24.5 \pm 1.0(96)$ & $44.5 \pm 3.1(48)$ \\
SIG & $37.2 \pm 1.6(96)$ & $3.1 \pm 0.1(24)$ & $9.8 \pm 0.6(96)$ & $40.4 \pm 3.4(48)$ & $105.8 \pm 5.3(24)$ \\
XIL & $19.0 \pm 0.9(24)$ & $9.5 \pm 0.6(24)$ & $3.8 \pm 0.4(48)$ & $4.5 \pm 0.3(96)$ & $132.5 \pm 6.1(24)$ \\
\hline
\end{tabular}

Volumetric Productivity $\left(\mathrm{U} . \mathrm{L}^{-1} \cdot \mathrm{h}^{-1}\right)$. Values in parentheses correspond to time of fermentation (h) when maximum results were observed. 


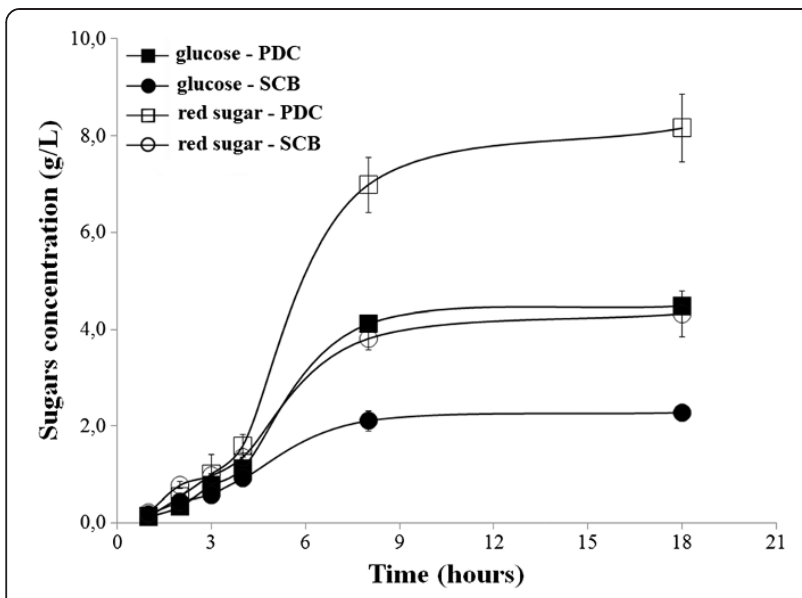

Figure 1 Hydrolysis of $10 \%$ (w/v) in natura sugarcane bagasse (SCB) and partially delignified cellulignin (PDC) using enzyme cocktails produced by $T$. harzianum L04. Concentrations of total reducing sugars and glucose during hydrolysis are indicated.

analyzed in this work, L04 showed a shorter acclimation period when cultivated in a complex substrate such as SCB. This observation is particularly interesting when compared to $T$. reesei Rut C30, a widely used filamentous fungus strain used for the production of cellulolytic enzymes (Peterson and Nevalainen 2012). T. reesei Rut C30 shows a longer acclimation to lignocellulosic feedstock

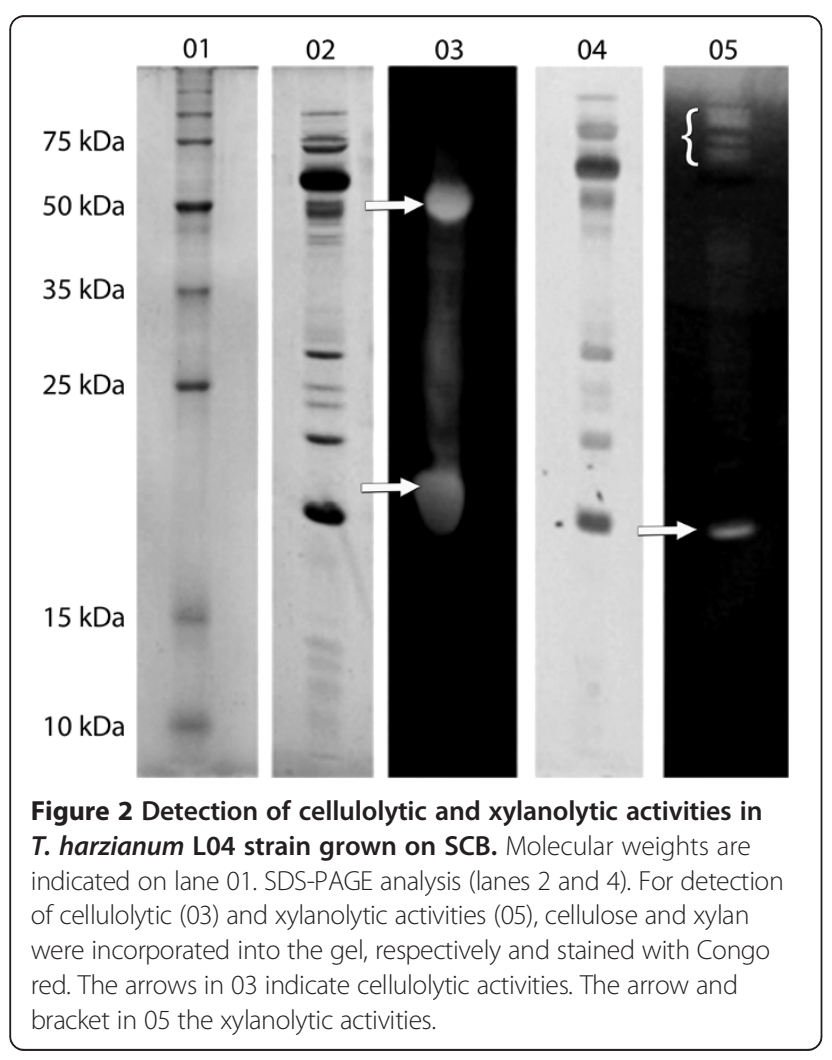

and is known to have a better performance for cellulase production when grown on pure cellulosic substrates then on lignocellulosic ones (Juhász et al. 2005), data confirmed by Castro et al. (2010c) where maximum values of volumetric productivity for $T$. reesei Rut C30 were obtained at 333 hours culture.

Strain L04 produced more xylanase, endoglucanase and $\beta$-glucosidase activities on different substrates irrespective of the carbon source (Table 2). The best results were obtained when L04 was grown on SCB. Partially delignified cellulignin (PDC) showed to be a poor inducer of L04 cellulases with delayed enzymatic production, contrary to expectations where delignification can improve enzyme production, since the large amount of lignin in SCB could irreversibly adsorb the enzymes produced during fungal cultivation. This would also be expected during hydrolysis where the absence of lignin probably reduces the adsorption of cellulolytic enzymes onto the lignin fraction of biomass (Berlin et al. 2005). This behavior was also reported for a T. harzianum strain isolated from the Amazon rainforest grown on pretreated sugarcane bagasse (Delabona et al. 2012).

The electrophoretic profile of L04 using SCB as substrate is similar to the one observed by Silva et al. (2012) using T. harzianum strain T4 cultivated in medium containing sugarcane bagasse. These authors showed by different electrophoretic techniques that $T$. harzianum was able to secret active multi enzymatic complexes with cellulolytic and xylanolytic activities which match the high molecular mass signal observed in L04 (Figure 2, lane 5). Both zymograms using CMC and xylan as substrate showed a signal around $20 \mathrm{kDa}$ (Figure 2, lanes 3 and 5). The weaker signal in the xylan zymogram indicates the presence of a $\sim 20 \mathrm{kDa}$ xylanolytic activity which is compatible with other studies of this species that describe xylanase activities around this molecular mass with the lack of cellulase activity (Rezende et al. 2002; Lee et al. 2009; do Vale et al. 2012). The L04 cellulase activity around $20 \mathrm{kDa}$ could correspond to the endoglucanase (EGIII) from T. harzianum IOC3844 characterized by Generoso et al. (2012) described with a low molecular mass, lack the cellulose binding domain (CBD) and able to degrade amorphous cellulose such as CMC.

In summary, L04 showed an interesting ability of producing significant yields of cellulase in a short culture time when grown on SCB. Also, it revealed a wellbalanced cellulolytic complex, presenting fast kinetics for production of endoglucanases, exoglucanases and $\beta$ glucosidases. About $60 \%$ glucose yields were obtained from SCB and PDC after 18 hours of hydrolysis. We propose that $T$. harzianum L04 should be considered as a potential candidate for on-site enzyme production using in natura sugarcane bagasse as carbon source, in ready supply in a bioethanol production plant. 


\section{Competing interests}

The authors declare that they have no competing interests.

\section{Authors' contributions}

BB carried out the isolation, characterization and classification of the fungi described in this work and wrote part of the manuscript. FAGT designed all the primers and supplied the equipment for fungi characterization. LMPM supervised the development of the work, analysed and discussed all the results, wrote the manuscript and supplied all the reagents and materials for this work. All authors read and approved the final manuscript.

\section{Acknowledgements}

This work was supported by Fundação de Apoio a Pesquisa (FAP/DF) and Conselho Nacional de Desenvolvimento Científico e Tecnológico (CNPq).

\section{Received: 22 August 2013 Accepted: 27 November 2013}

\section{Published: 6 December 2013}

\section{References}

Ahmed S, Bashir A, Saleem H, Saadia M, Jamil A (2009) Production and purification of cellulose-degrading enzymes from a filamentous fungus Trichoderma harzianum. Pak J Bot 41:1411-1419

Andreaus J, Filho EXF, Bom EPS (2008) Biotechnology of holocellulose-degrading enzymes. In: Hou CT, Shaw JR (ed) Biocatalysis and Bioenergy. Copyright, New Jersey, USA, pp 197-229

Arantes V, Saddler JN (2010) Access to cellulose limits the efficiency of enzymatic hydrolysis: the hole of amorphogenesis. Biotechnol Biofuels 3:4

Bailey MJ, Biely P, Poutanen K (1992) Interlaboratory testing of methods for assay of xylanase activity. J Biotechnol 23:257-270

Banerjee G, Scott-Craig JS, Walton JD (2010) Improving enzymes for biomass conversion: a basic research perspective. Bioenergy Res 3:82-92

Berlin A, Gilkes N, Kilburn D, Bura R, Markov A, Skomarovsky A, Okunev O, Gusakov A, Gregg D, Sinitsyn A, Saddler J (2005) Evaluation of novel fungal cellulase preparations for ability to hydrolyze softwood substrates-evidence for the role of accessory enzymes. Enzym Microb Tech 37:175-184

Betancur GJV, Pereira N, Jr (2010) Sugarcane bagasse as feedstock for second generation ethanol production. Part l: diluted acid pretreatment optimization. Electron J Biotechnol 13:01-08

Bradford MM (1976) A rapid and sensitive method for the quantitation of microgram quantities of protein utilizing the principle of protein-dye binding. Anal Biochem 72:248-254

Canilha L, Chandel AK, Milessi TSS, Antunes FAF, Freitas WLC, Felipe MGA, Silva SS (2012) Bioconversion of sugarcane biomass into ethanol: an overview about composition, pretreatment methods, detoxification of hydrolysates, enzymatic saccharification, and ethanol fermentation. J Biomed Biotechnol 2012:989572

Castro AM, Carvalho MLA, Leite SGF, Pereira N, Jr (2010a) Cellulases from Penicillium funiculosum: production, properties and application to cellulose hydrolysis. J Ind Microbiol Biotechnol 37:151-158

Castro AM, Ferreira MC, Cruz JC, Pedro KCNR, Carvalho DF, Leite SGF, Pereira N, Jr (2010b) High-yield endoglucanase production by Trichoderma harzianum IOC-3844 cultivated in pretreated sugarcane mill byproduct. Enzyme Res 2010:854526

Castro AM, Pedro K, da Cruz J, Ferreira M, Ferreira MC, Leite SGF, Pereira N, Jr (2010c) Trichoderma harzianum IOC-4038: a promising strain for the production of a cellulolytic complex with significant beta-glucosidase activity from sugarcane bagasse cellulignin. Appl Biochem Biotechnol 162:2111-2122

Delabona PS, Farinas CS, Silva MR, Azzoni SF, Pradella JGC (2012) Use of a new Trichoderma harzianum strain from the Amazon rainforest with preteated sugar cane bagasse for on-site cellulase production. Bioresour Technol 107:517-521

do Vale LHF, Gómez-Mendonza DP, Kim MS, Pandey A, Ricart CAO, Filho EXF, Sousa M (2012) Secretome analysis of the fungus Trichoderma harzianum grown on cellulose. Proteomics 12:2716-2728

Druzhinina IS, Kopchinskiy AG, Komón M, Bissett J, Szakacs G, Kubicek CP (2005) An oligonucleotide barcode for species identification in Trichoderma and Hypocrea. Fungal Genet Biol 42:813-828

Ewing B, Hillier L, Wendl M, Green P (1998) Basecalling of automated sequencer traces using PHRED. I. Accuracy assessment. Genome Res 8:175-185

FAOSTAT (2012). Available from: http://faostat.fao.org. Accessed October 5, 2012
Franco P, Ferreira H, Ferreira E (2004) Production and characterization of hemicellulase activities from Trichoderma harzianum strain T4. Biotechnol Appl Biochem 40:255-259

Generoso WC, Malago-Jr W, Pereira N, Jr, Henrique-Silva F (2012) Recombinant expression and characterization of an endoglucanase III (cel12a) from Trichoderma harzianum (Hypocreaceae) in the yeast Pichia pastoris. Genet Mol Res 11:1544-1557

Ghose TK (1987) Measurement of cellulase activities. Pure Appl Chem 59:257-268

Himmel ME, Ruth MF, Wyman CE (1999) Cellulase for commodity products from cellulosic biomass. Curr Opin Biotechnol 10:358-364

Jeewon R, Hyde KD (2007) Detection and diversity of fungi from environmental samples: traditional versus molecular approaches. In: Varma A, Oelmüller R (ed) Soil biology: advanced techniques in soil microbiology, vol. 11. Springer-Verlag, Berlin Heidelberg

Juhász T, Szengyel Z, Réczey K, Siika-Aho M, Viikari L (2005) Characterization of cellulases and hemicellulases produced by Trichoderma reesei on various carbon sources. Process Biochem 40:3519-3525

Kumar R, Singh S, Singh OV (2008) Bioconversion of lignocellulosic biomass: biochemical and molecular perspectives. J Ind Microbiol Biotechnol 35:377-391

Lee JM, Shin JW, Nam JK, Choi JY, Han IS, Nam SW, Choi YJ, Chung DK (2009) Molecular cloning and expression of the Trichoderma harzianum C4 endo- $\beta-1,4-x y l a n a s a$ gene in Saccharomyces cerevisiae. J Microbiol Biotechnol 19:823-828

Maeda RN, Serpa VI, Rocha VAL, Mesquita RAA, Anna LMMS, Castro AM, Driemeier CE, Pereira N, Jr, Polikarpov I (2011) Enzymatic hydrolysis of pretreated sugar cane bagasse using Penicillium funiculosum and Trichoderma harzianum cellulases. Process Biochem 46:1196-1201

Mandels M, Weber J (1969) The production of cellulases. Adv Chem Ser 95:391-414

Miller GL (1959) Use of dinitrosalicylic acid reagent for determination of reducing sugar. Anal Chem 31:426-428

Montenecout BS, Eveleigh DE (1977) Preparation of mutants of Trichoderma reesei with enhanced cellulase production. Appl Environ Microbiol 34:777-782

Moreira LRS, Ferreira GV, Santos SST, Ribeiro APS, Siqueira FG, Filho EXF (2012) The hydrolysis of agro-industrial residues by holocellulose-degrading enzymes. Braz J Microbiol 43:498-505

Myers N, Mittermeier RA, Mittermeier CG, Fonseca GAB, Kent J (2000) Biodiversity hotspots for conservation priorities. Nature 403:853-858

Parachin NS, Siqueira S, de Faria FP, Torres FAG, de Moraes LMP (2009) Xylanases from Cryptococcus flavus isolate 1-11: enzymatic profile, isolation and heterologous expression of CXXYN1 in Saccharomyces cerevisiae. J Mol Catal B Enzym 59:52-57

Peterson R, Nevalainen H (2012) Trichoderma reesei RUT-C30-thirty years of strain improvement. Microbiology 158:58-68

Rezende MI, Barbosa AM, Vasconcelos AFD, Endo AS (2002) Xylanase production by Trichoderma harzianum rifai by solid state fermentation on sugarcane bagasse. Braz J Microbiol 33:67-72

Roeder V, Broda P (1987) Rapid preparation of DNA from filamentous fungi. Lett Appl Microbiol 1:17-20

Ruegger MJS, Tauk-Tornisielo SM (2004) Atividade da celulase de fungos isolados do solo da Estação Ecológica de Juréia-Itatins, São Paulo, Brasil. Rev Bras Bot 27:205-211

Sambrook J, Russel DW (2001) Molecular cloning-a laboratory manual, 3rd edition. Cold Spring Harbor Laboratory Press, New York

Silva AJ, Gómez-Mendonza DP, Junquira M, Domoni GB, Ximenes-Filho E, Sousa MV, Ricart CAO (2012) Blue native-PAGE analysis of Trichoderma harzianum secretome reveals cellulases and hemicellulases working as multienzymatic complexes. Proteomics 12:2729-2738

Siqueira FG, Siqueira AG, Siqueira EG, Carvalho MA, Peretti BMP, Jaramilho PMD, Teixeira RSS, Dias ES, Félix CR, Filho EXF (2010) Evaluation of holocellulase production by plant-degrading fungi grown on agro-industrial residues. Biodegradation 21:815-824

Sun X, Liu Z, Zheng K, Song X, Qu Y (2008) The composition of basal and induced cellulase systems in Penicillium decumbens under induction or repression conditions. Enz Microb Technol 42:560-567

Szijártó N, Szengyel Z, Lidén G, Réczey K (2004) Dynamics of cellulase production by glucose grown cultures of Trichoderma reesei Rut- $C 30$ as a response to addition of cellulose. Appl Biochem Biotechnol 113:115-124

Tamura K, Dudley J, Nei M, Kumar S (2007) MEGA4: molecular evolutionary genetics analysis (MEGA) software version 4.0. Mol Biol Evol 24:1596-1599 
Tolan JS (2002) logen's process for producing ethanol from cellulosic biomass. Clean Technol Envir 3:339-345

White TJ, Bruns T, Lee S, Taylor J (1990) Amplification and direct sequencing of fungal ribosomal RNA genes for phylogenetics. In: Innis MA, Gelfand DH, Sninsky JJ, White TJ (ed) PCR Protocols: a guide to methods and applications. Academic Press, New York, USA, pp 315-322

doi:10.1186/2193-1801-2-656

Cite this article as: Benoliel et al:: A novel promising Trichoderma harzianum strain for the production of a cellulolytic complex using sugarcane bagasse in natura. SpringerPlus 2013 2:656.

Submit your manuscript to a SpringerOpen ${ }^{\circ}$ journal and benefit from:

- Convenient online submission

- Rigorous peer review

- Immediate publication on acceptance

- Open access: articles freely available online

- High visibility within the field

- Retaining the copyright to your article

Submit your next manuscript at $\gg$ springeropen.com 